\title{
Exchange Rate Pass-Through to Domestic Prices: The Turkish Case (2002-2014)
}

\author{
İlyas Şıklar \\ Anadolu University, Eskisehir, Turkey \\ E-mail: isiklar@anadolu.edu.tr \\ Merve Kocaman \\ Anadolu University, Eskisehir, Turkey \\ E-mail: mervealtin@ anadolu.edu.tr \\ Sevcan Kapkara \\ Anadolu University, Eskisehir, Turkey \\ E-mail: skapkara@anadolu.edu.tr
}

Received: November 4, 2016

Accepted: November 30, 2016

doi:10.5296/ber.v7i2.11541

URL: https://doi.org/10.5296/ber.v7i2.11541

\begin{abstract}
This study examines the degree of exchange rate pass through (ERPT) into producer prices and consumer prices in Turkey. To see the effect of ERPT, recursive vector autoregressive (VAR) model on monthly data from January 2002 to November 2014 is used. Model includes six variables which are oil prices that represent supply shock, industry production index representing demand shocks, reserve money representing monetary policy, nominal exchange rate and CPI-PPI indices. Obtained results show that although there is a pass through from exchange rate to consumer and producer prices, its degree is not as effective as prior to 2001 . This means that policymakers have more power for pursuing independent monetary policy.
\end{abstract}

Keywords: Exchange rate, Pass through effect, Consumer prices, Producer prices

Jel codes: F31, E31, E52 


\section{Introduction}

With the increasing technology, investing to the foreign countries has been getting easier since 1990s. Especially technologic improvements in financial sector make flow of foreign capital easier. Therefore, since 1990s, both direct and portfolio investments to the foreign countries have been increased. Also, open economy policies of developed and developing countries contribute to this financial globalization process.

Thru floating capital, portfolio investments are effective especially on the countries' exchange rate. Country's exchange rate has a crucial importance on macroeconomic stability of the country, especially its effect on the domestic prices is one of the seriously searched topics. Exchange rate changes' effect on the domestic prices of a country is named as Exchange Rate Pass-Through (ERPT).

Goldberg and Knetter (1997) defined the ERPT as "the percentage change in local currency import prices resulting from a one percentage change in the exchange rate between the exporting and the importing countries". More basically, pass through can be expressed as the effect of $1 \%$ change in exchange rate to the domestic prices. If firms reflect this change to the prices as one to one, this means there is full or complete pass through, if firms reflect this change's some parts to the prices, this means there is incomplete pass through and if firms do not change their prices after change in exchange rate, this means there is no pass through (Yang, 1997: 95). As Dornbusch (1987) stated, incomplete pass through can stem from oligopolistic competition and structure of import and domestic goods which are imperfect substitutes.

Changes in exchange rate can show its effects on domestic prices with two ways: directly and indirectly. Firstly, with the increase in imported intermediate good prices, in terms of domestic prices, production cost increases. This rises general price level in the country. Also, with the increase in imported final goods prices, in terms of domestic prices, general price level increases. These two are the direct effects. Indirect effect realizes via export channel. If domestic currency depreciates, this causes increase in foreign demand for country's exported goods. Also, since depreciation of the local currency makes more expensive imported goods, domestic demand to import substitutes will increase. In addition to these, increase in price of intermediate goods that realized directly, causes to increase production costs of exporters. This reflects to prices as well. These three cases cause to rise export and import substitute goods' prices which also rise the general price level in the country (Kiptiu et al [2005] and Hyder and Shah [2003] in Ar1, 2010: 2835-2836).

The size and openness of an economy is important for degree of pass through effect. Also, the degree of ERPT is important to observe and predict the inflation rate so to conduct required monetary policy (Devereux, Lane and Xu, 2006).

This study investigates the ERPT in Turkey for the period from 2002 to 2014 using monthly data. Firstly, literature related with the ERPT in both world and Turkey is examined, then methodology of the study is presented, data and statistical properties and empirical results are explained and finally conclusion is exhibited. 


\section{Literature Review}

There are considerable amount of theoretical and empirical studies on the ERPT to CPI and PPI. To show the short literature of exchange rate pass through mechanism in theory and in practice, some of the selected studies are summarized below.

McCarthy (2000) investigated the impact of exchange rates and import prices on the domestic producer price index and consumer price index in selected industrialized economies for the period between 1976 and 1998. The mentioned study concludes that the pass-through to aggregate consumer prices, which is the principal concern for monetary policy, is modest in most of the industrialized countries. Moreover, these factors had a disinflationary effect during the late 1990s in many of these countries.

Leigh and Rossi (2002) used a recursive vector autoregression model, suggested by McCharty (1999) to indicate pass-through effect from the nominal exchange rate to wholesale and consumer prices. Obtained results show that the impact of exchange rate is generally felt in the first four months for Turkey. Also, compared with the CPI, the pass through via wholesale prices are more definite.

Hüfner and Schröder (2002) analyzed the ERPT effect to consumer prices for the selected European countries. Using time series data from 1981 to 2001 they calculated the weights of the Harmonized Index of Consumer Prices (HICP) and computed a weighted average of the country results for the selected countries. These countries are Germany, Italy, France, the Netherlands and Spain. According to their results, while the country that exhibits the fastest ERPT to consumer prices is Netherlands, Italy and France have the highest effects in the long run.

Arbatl1 (2005) seeks pass-through effect for Turkey with using the VAR framework while the possibility of asymmetries in the pass through is assessed by using Threshold VAR (TVAR) models. He estimated several TVAR models to find remarkable asymmetries in the relationship between exchange rate and inflation as measured by wholesale and CPI. The study's results show that in the economic contraction periods pass-through to prices is lower. Arbatl1 (2005) concludes that evidence for asymmetries that stem from the magnitude of change in exchange rates is weaker and quantitatively not very significant.

Kara et. al. (2005) analyzed the impact of exchange rates on domestic prices in Turkey. They aimed to show the variations in the exchange rate regimes and identified the determinants of this change. Also, they characterized the degree and extend of pass through across different sub-sectors. The study's empirical results show that compared with the pre-2001 period, the ERPT to domestic prices has significantly declined. Also, results show that changing the exchange rate regime from fixed to floating one and decisiveness for fight against inflation create significant decline in pass through. In spite of these results, they indicate that the exchange rate have still an effect on inflation particularly on the traded goods.

Şıklar and Çağlarırmak (2007) aimed to examine ERPT on domestic consumer and producer prices for Turkey. They used VECM method and evaluated the influence of monetary policy on ERPT. Findings of this study show that there is incomplete and decreasing ERPT to 
inflation in Turkey.

Masha and Park (2012), with using recursive VAR analysis, investigated the degree of exchange rate pass-through into consumer and producer price in Maldives. Compared with other countries, ERPT to consumer prices is quite high. Moreover, they reached that ERTP to CPI and PPI is important, but not complete. Impact of exchange rate changes reflect on the second year.

To estimate the exchange rate pass-through in Turkey for the period between 1986-2013, Arslaner et. al. (2014) used error correction model. Results show that there is a substantial degree of ERPT for Turkey to domestic inflation. Moreover, greater part of the pass-through realize almost instantaneously. Also, they reached that when the data frequency falls, the degree of ERPT increases. Moreover, results reveal that the high degree of openness of the economy and past currency crises are the main factors that contribute to high pass through.

Choudhri and Hakura (2015) used both regression and VAR-based estimates in their study. The study concludes that for large number of countries ERPT to import prices is incomplete and compared with the export prices it is larger. They used dynamic general equilibrium model and reached that to explain the pass-through evidence even with a constant markup, a mix of producer and local currency pricing can be analyzed.

Savoie and Khan (2015) also searched ERPT to CPI and discussed the implications of ERPT for the monetary policy conduction. In their study, they found evidences which prove that ERPT has played an important role in recent inflation dynamics in Canada.

\section{Methodology}

In this study, to analyze the degree of exchange rate pass through to domestic prices, recursive VAR method is used following McCarthy (1999). Used data is monthly from 2002 to 2014. To estimate the model, six variables are used. Included variables are nominal exchange rate, oil prices, proxies for supply shocks and demand shocks, proxy for monetary policy and CPI-PPI indices. To represent the supply shock in the economy, oil prices that are expressed in domestic currency; to represent the demand shocks, industrial production and to represent the monetary policy the reserve money is used.

Most exogenous variables are ordered in the first rank in the VAR system. It is found by using the Cholesky Decomposition. Oil prices, industrial production and exchange rate are the most exogenous variables so they are ordered before the price variables. Following Ş1klar and Çağlarırmak's study (2007) the estimated system can be represented as;

$$
\begin{gathered}
\Pi_{t}^{o i l}=E_{t-1}\left[\Pi_{t}^{o i l}\right]+\delta_{t}^{o i l} \\
\Delta y_{t}=E_{t-1}\left[\Delta y_{t}\right]+\alpha_{1} \delta_{t}^{o i l}+\delta_{t}^{\Delta y} \\
\Delta R M_{t}=E_{t-1}\left[\Delta R M_{t}\right]+\lambda_{1} \delta_{t}^{o i l}+\lambda_{2} \delta_{t}^{\Delta y}+\delta_{t}^{\Delta R M} \\
\Delta e_{t}=E_{t-1}\left[\Delta e_{t}\right]+\varphi_{1} \delta_{t}^{o i l}+\varphi_{2} \delta_{t}^{\Delta y}+\varphi_{3} \delta_{t}^{\Delta R M}+\delta_{t}^{\Delta e_{t}}
\end{gathered}
$$




$$
\begin{gathered}
\Pi_{t}^{P P I}=E_{t-1}\left[\Pi_{t}^{P P I}\right]+\rho_{1} \delta_{t}^{o i l}+\rho_{2} \delta_{t}^{\Delta y}+\rho_{3} \delta_{t}^{\Delta R M}+\rho_{4} \delta_{t}^{\Delta e_{t}}+\delta_{t}^{P P I} \\
\Pi_{t}^{C P I}=E_{t-1}\left[\Pi_{t}^{C P I}\right]+\psi_{1} \delta_{t}^{o i l}+\psi_{2} \delta_{t}^{\Delta y}+\psi_{3} \delta_{t}^{\Delta R M}+\psi_{4} \delta_{t}^{\Delta e_{t}}+\psi_{5} \delta_{t}^{P P I}+\delta_{t}^{C P I}
\end{gathered}
$$

In this model, $\Pi_{t}^{o i l}, y_{t}, R M_{t}, e_{t}, \Pi_{t}^{P P I}$ and $\Pi_{t}^{C P I}$ stand for oil price inflation, industrial production index, reserve money, nominal exchange rate, inflation in producer prices and inflation in consumer prices. The components represent that the first is the expected inflation at that stage based on the available information at the end of period $t-1$. The second and third are effects of period t supply and demand shocks on inflation. The fourth is the growth in reserve money that is used to include monetary policy in the model. The next is the effects of exchange rate shocks on inflation at the previous stages of the distribution chain. Lastly, inflation shock takes part in the model.

Here $\delta_{t}^{o i l}, \delta_{t}^{\Delta y}$ and $\delta_{t}^{\Delta e_{t}}$ represent the supply, demand and exchange rate shocks respectively. $\delta_{t}^{P P I}$ and $\delta_{t}^{C P I}$ are the producer price and consumer price shocks; and $E_{t-1}$ expectations of a variable conditional on the information set at the end of period t-1.

As it is seen, variables in the first group are independent from the exchange rate at date $t$. This means that while they are not simultaneously be affected by exchange rate shocks, they can affect exchange rate together. Moreover, the effects of changes in exchange rate on domestic prices are modeled in last two equations. These equations between variables are estimated by using VAR scheme.

With estimating VAR model, impulse-response functions are obtained. These functions show the impact of a temporary shock to one variable on the other variables.

\section{Data}

Empirical estimation is based on monthly observations from 2002M1 to 2014M11. To see whether series are stationary or not, unit root tests are conducted. Applied unit root tests are Augmented Dickey Fuller and Phillips Perron unit root tests. Results of the ADF and PP tests can be seen at Table 1.

Table 1. ADF and PP Unit Root Tests

\begin{tabular}{|c|c|c|c|c|c|c|c|c|}
\hline Tests & \multicolumn{4}{|c|}{ ADF } & \multicolumn{4}{c|}{ PP } \\
\hline Degree & \multicolumn{2}{|c|}{ Level } & \multicolumn{2}{|c|}{ First Difference } & \multicolumn{2}{c|}{ Level } & \multicolumn{2}{c|}{ First Difference } \\
\hline Variables & t-stat. & Prob. & t-stat. & Prob. & t-stat. & Prob. & t-stat. & Prob. \\
\hline loil & $-2.304608^{*}$ & 0.1719 & $-8.950487^{*}$ & 0.0000 & $-2.288677^{*}$ & 0.1770 & $-8.936431^{*}$ & 0.0000 \\
\hline lcpi & $-2.526281^{*}$ & 0.1112 & $-6.745902^{*}$ & 0.0000 & 8.075996 & 1.0000 & -6.592669 & 0.0000 \\
\hline ler & 0.843399 & 0.8918 & -8.981667 & 0.0000 & $-0.684592^{*}$ & 0.8464 & $-8.575580^{*}$ & 0.0000 \\
\hline lppi & $-2.240003^{*}$ & 0.1932 & $-6.943781^{*}$ & 0.0000 & 5.075983 & 1.0000 & -6.080933 & 0.0000 \\
\hline lrm & $-0.220648^{*}$ & 0.9320 & $-4.258744^{*}$ & 0.0007 & $-0.464209^{*}$ & 0.8937 & $-18.26713^{*}$ & 0.0000 \\
\hline lipi & 1.395072 & 0.9590 & -2.159865 & 0.0301 & $-2.423948^{*}$ & 0.1368 & $-37.91144^{*}$ & 0.0001 \\
\hline
\end{tabular}

*includes constant 


\section{Macrothink}

Business and Economic Research

ISSN 2162-4860

2017, Vol. 7, No. 2

As it is indicated, all variables in logarithm have I (1) order of integration. To see whether variables are co-integrated or not, trace and maximum eigenvalue tests are conducted. While trace test indicated that there is 3 co-integration, maximum eigenvalue test indicates that there is 2 co-integration between variables. Therefore, in this study, to measure the pass through effect from the nominal exchange rate to the producer and consumer prices, vector error correction model (VECM) is used. Number of included lags are 2, which is determined according to AIC criteria.

\section{Empirical Results}

To show the effect of exchange rate behaviors on domestic prices, impulse response functions are used. Figure 1 exhibits the results of impulse-response functions. As it is seen, exchange rate pass through to domestic prices works positively. One standard deviation innovation in exchange rate causes increase in CPI and PPI.
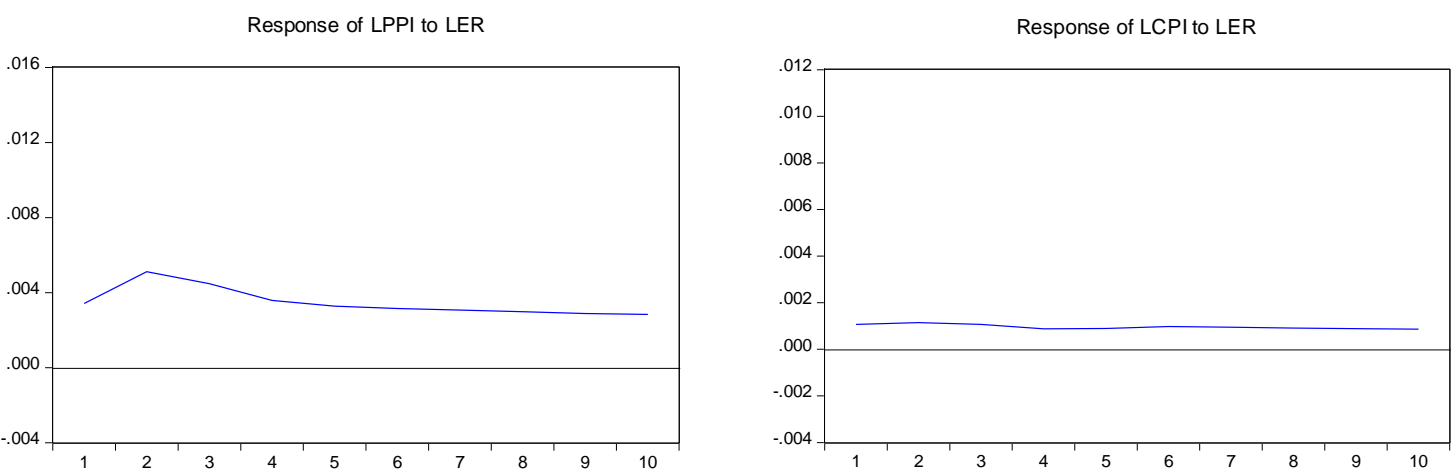

Response of LER to LER

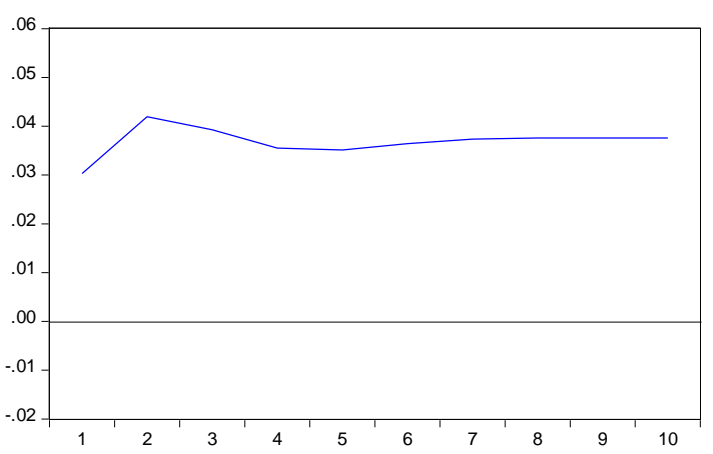

Figure 1. Impulse Responses of Domestic Prices to One Standard Deviation Innovation in Exchange Rate

To estimate the ERPT coefficient using impulse response functions, cumulative change in each price index is divided by the cumulative change in exchange rate in one period to the other. The pass-through coefficient is formulated as;

$$
P T C_{t+j}^{C P I}=\frac{\sum_{\mathrm{i}=\mathrm{t}}^{\mathrm{t}+\mathrm{j}} \Delta \Pi_{i}^{C P I}}{\sum_{\mathrm{i}=\mathrm{t}}^{\mathrm{t}+\mathrm{j}} \Delta e_{i}} \quad \text { and } \quad P T C_{t+j}^{P P I}=\frac{\sum_{\mathrm{i}=\mathrm{t}}^{\mathrm{t}+\mathrm{j}} \Delta \Pi_{i}^{P P I}}{\sum_{\mathrm{i}=\mathrm{t}}^{\mathrm{t}+\mathrm{j}} \Delta e_{i}}
$$

Where $\mathrm{PT}_{\mathrm{t}, \mathrm{t}+\mathrm{j}}$ and $\mathrm{E}_{\mathrm{t}, \mathrm{t}+\mathrm{j}}$ are cumulative changes in the price level and exchange rate respectively between $t$ and $t+j$ months. 


\section{Macrothink}

Business and Economic Research ISSN 2162-4860 2017, Vol. 7, No. 2

With using the impulse response functions, cumulative pass through coefficients are obtained. These coefficients are exhibited in Figure 2. As seen in the Figure 2, CPI coefficients are greater than the PPI coefficients and they reflect increasingly. This means that the exchange rate pass through is more pronounced in CPI as compared to PPI.

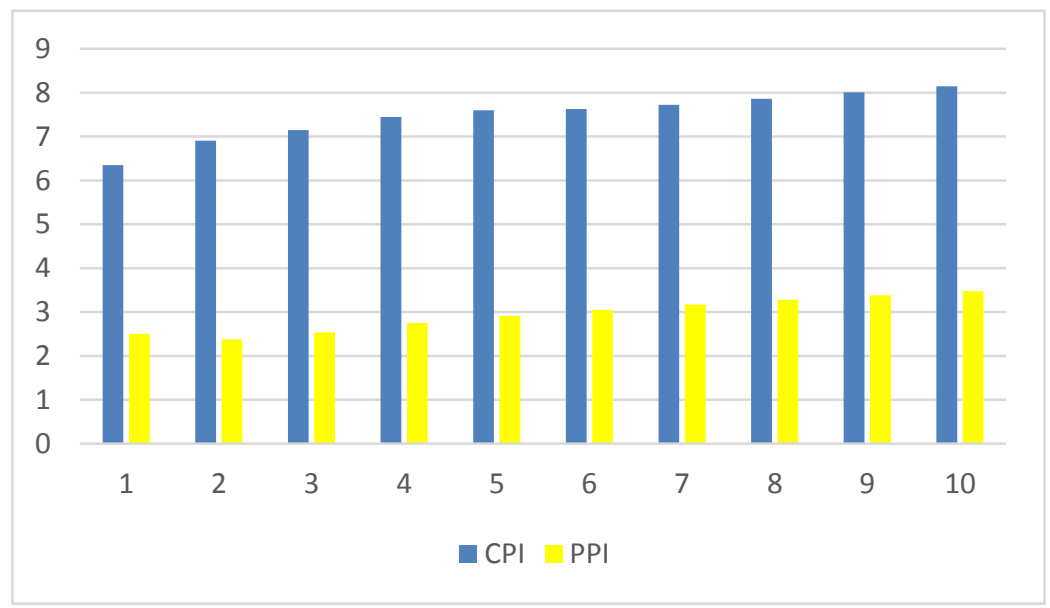

Figure 2. Estimated Cumulative Pass Through Coefficients

The variance decomposition lets us to analyze the importance of exchange rate shocks in clarifying PPI and CPI inflation movements over the sample period. Table 2 and Table 3 also show the variance decomposition functions of CPI and PPI for 10 month terms. This functions gives information about how much amount of proportional change's stemmed from variables itself and how much amount stemmed from other variables in the system.

Table 2. Variance Decomposition of CPI

\begin{tabular}{|c|c|c|c|c|c|c|c|}
\hline Period & S.E. & LOILP & LIPI & LRM & LER & LPPI & LCPI \\
\hline 1 & 0.007648 & 0.472259 & 0.357587 & 0.433238 & 1.959615 & 17.64286 & 79.13444 \\
\hline 2 & 0.013256 & 0.705778 & 0.280567 & 0.212009 & 1.403462 & 29.67979 & 67.71839 \\
\hline 3 & 0.017628 & 1.758895 & 0.639768 & 0.122202 & 1.161867 & 36.45175 & 59.86552 \\
\hline 4 & 0.021235 & 3.064646 & 1.181021 & 0.084643 & 0.973981 & 40.74535 & 53.95036 \\
\hline 5 & 0.024291 & 4.158164 & 1.342900 & 0.072031 & 0.880812 & 42.92224 & 50.62385 \\
\hline 6 & 0.026989 & 4.872645 & 1.456569 & 0.062082 & 0.845559 & 43.73751 & 49.02564 \\
\hline 7 & 0.029490 & 5.358742 & 1.486868 & 0.052502 & 0.812459 & 44.00319 & 48.28624 \\
\hline 8 & 0.031829 & 5.664525 & 1.471558 & 0.045362 & 0.779673 & 44.03603 & 48.00285 \\
\hline 9 & 0.034036 & 5.880873 & 1.459573 & 0.039682 & 0.749719 & 44.01127 & 47.85889 \\
\hline 10 & 0.036131 & 6.063571 & 1.445656 & 0.035220 & 0.723096 & 43.99818 & 47.73427 \\
\hline
\end{tabular}


Table 3. Variance Decomposition of PPI

\begin{tabular}{|c|c|c|c|c|c|c|c|}
\hline Period & S.E. & LOILP & LIPI & LRM & LER & LPPI & LCPI \\
\hline 1 & 0.010789 & 26.15012 & 0.476190 & 0.286766 & 10.04619 & 63.04073 & 0.000000 \\
\hline 2 & 0.020020 & 36.72120 & 0.145350 & 0.451796 & 9.432767 & 52.67422 & 0.574665 \\
\hline 3 & 0.027657 & 41.60778 & 0.233810 & 0.396957 & 7.556174 & 48.60925 & 1.596034 \\
\hline 4 & 0.034110 & 44.64407 & 0.153964 & 0.267297 & 6.074273 & 45.62445 & 3.235948 \\
\hline 5 & 0.039673 & 46.07801 & 0.123545 & 0.198787 & 5.172350 & 43.26115 & 5.166159 \\
\hline 6 & 0.044901 & 46.82366 & 0.120460 & 0.157777 & 4.530495 & 41.35984 & 7.007761 \\
\hline 7 & 0.049847 & 47.21998 & 0.135351 & 0.133343 & 4.054857 & 39.86068 & 8.595785 \\
\hline 8 & 0.054512 & 47.45732 & 0.146518 & 0.118646 & 3.688633 & 38.70449 & 9.884392 \\
\hline 9 & 0.058933 & 47.63396 & 0.157203 & 0.110764 & 3.396201 & 37.79847 & 10.90340 \\
\hline 10 & 0.063116 & 47.77450 & 0.166975 & 0.105502 & 3.163299 & 37.07226 & 11.71746 \\
\hline
\end{tabular}

Variance decomposition functions show that in the long run while $0.72 \%$ of variance in CPI stems from exchange rate, $47.7 \%$ of variance stems from itself. Also, while $3.16 \%$ of variance in PPI arises from exchange rate, $47.7 \%$ of variance arises from oil prices. This shows that exchange rate pass through to domestic prices is pretty low for Turkey. It is also proof of the case that exchange rate pass through effect decreased with the floating regime that is started to conduct 22 February 2001.

\section{Conclusion}

In the sensitive and intensive interaction environment that is created by global economic system, changes that occurred in the exchange rate has a big importance and impact on the countries' macroeconomic indicators. For this reason, for an economy that especially aims to provide and sustain price stability, observing the changes in exchange rate carries weight. With this way, countries can estimate how their economy will be effected in case of an exchange rate shock and they can take precautions depending on this information.

In the literature, the effect of changes in exchange rate to the domestic prices is explained by ERPT effect. In this context, in this study, it is tried to measure the ERPT in Turkey with monthly data from 2002 January to 2014 December. The dynamics of exchange rate pass through was derived from a recursive distribution chain model, based on McCharty (1999). Obtained results show that ERPT is pretty low in Turkey between these years. Also, when we compare before 2001 and between 2002 and 2014, it is seen that the impact of ERPT is less often in the examined term. This result is quite suitable for policymakers, since lower ERPT to domestic prices provides more freedom for pursuing independent monetary policy.

\section{References}

Arbatl1, E. C. (2005). Exchange Rate Pass-Through in Turkey: Looking for Asymmetries, Johns Hopkings University Working Paper Series No: 113. File URL: http://www.tcmb.gov.tr/wps/wcm/connect/TCMB+TR/TCMB+TR/Main+Menu/Yayinlar/Cen tral+Bank+Review/Central+Bank+Review/2003/Sayi+3-2/

Ayşe, A. (2010), Dalgalanma Korkusu ve Döviz Kuru Geçiş Etkisi. Journal of Yaşar 
University, 5(17), 2832-2841. File URL:

http://journal.yasar.edu.tr/wp-content/uploads/2012/08/No17Vol5_2_Ari.pdf

Aslaner et. al. (2014). The Relationship between Inflation Targeting and Exchange Rate Pass-Through in Turkey with a Model Averaging Approach, TCMB Working Paper No: 14/16. FileURL:http://www.tcmb.gov.tr/wps/wcm/connect/TCMB+EN/TCMB+EN/Main+Menu/PU BLICATIONS/Research/Working+Paperss/2014/14-16

Choudhri, E. U., \& Hakura D. S. (2015). The Exchange Rate Pass-Through to Import and Export Prices: The Role of Nominal Rigidities and Currency Choice. Journal of International Money and Finance, 51, 1-25. https://doi.org/10.1016/j.jimonfin.2014.09.006

Devereux, M. B., Lane, P. R., \& Xu, J. (2006). Exchange Rates and Monetary Policy in Emerging Market Economies. The Economic Journal, 116(511), 478-506.

https://doi.org/10.1111/j.1468-0297.2006.01089.x

Goldberg, P. K. , \& Knetter, M. M. (1997). Goods Prices and Exchange Rates: What Have We Learned? Journal of Economic Literature, 35(3), 1243-72. https://doi.org/10. 3386/w5862

Hüfner, F. P., \& Schröder, M. (2002). Exchange rate pass-through to consumer prices: A European perspective. https://doi.org/10.2139/ssrn.304939

Kara H. et. al. (2005). Exchange Rate Pass- Through in Turkey: Has It Changed and to What Extend, The Central Bank of the Republic of Turkey Working Paper No: 05/04.

Leigh D., \& Rossi M. (2002). Exchange Rate Pass-Through in Turkey, IMF Working Paper No: 02/204. Available at SSRN: https://ssrn.com/abstract $=880852$

Masha I., \& Park C. (2012). Exchange Rate Pass Through to Prices in Maldives, IMF Working Paper Series No: 12/126. Available at SSRN: https://ssrn.com/abstract=2127021

McCarthy, J. (2000). Pass-Through of Exchange Rates and Import Prices to Domestic Inflation in Some Industrialized Economies, Fedaral Reserve Bank of New York No: 111. https://doi.org/10.2139/ssrn.856284

Savoie L., \& Khan M. (2015). Exchange Rate Pass-Through to Consumer Prices: Theory and Recent Evidence. Bank of Canada Discussion Paper, 9, 1-11.

https://www.econstor.eu/bitstream/10419/129689/1/83774637X.pdf

Siklar I., \& Caglarirmak, N. (2007). Exchange Rate Pass-Through to Domestic Prices: The Turkish Case (1994-2006), The Business Review, 8(1), 162-169.

Yang, J. (1997). Exchange rate pass-through in US manufacturing industries. Review of Economics and Statistics, 79(1), 95-104. https://doi.org/10.1162/003465397556430 


\section{Copyright Disclaimer}

Copyright for this article is retained by the author(s), with first publication rights granted to the journal.

This is an open-access article distributed under the terms and conditions of the Creative Commons Attribution license (http://creativecommons.org/licenses/by/3.0/). 